\title{
GOVERNANCE IN THE MULTIMEDIA CLUSTER OF MONTREAL ${ }^{1}$
}

\author{
Diane-Gabrielle Tremblay and Serge Rousseau ${ }^{2}$
}

\section{Resume:}

The multimedia sector is one of the high-tech sectors that has contributed greatly to revitalizing the economic base of the Montreal region. A relatively young sector, which may be described as post-industrial, it has created high expectations as to its capacity to create jobs and economic wealth. Its many applications have created visions of sustained growth, arousing the interest of many public and private actors in the sector. The sector has fulfilled its promises in part and met a number of expectations, to such an extent that for a number of years it actually experienced labour shortage, raiding of workers, high wages, the creation of many firms and significant interest on the part of the financial community (Tremblay, 2002, 2004; Tremblay et al., 2002). In short, for a few years the sector was an unqualified success.

This paper will examine the mechanisms of governance set up by actors in the Montreal region in order to build the foundations of a new industry. We will also see that governance has evolved over the years according to information and changes in the environment and involves a diversity of actors.

\section{Introduction}

The multimedia sector is one of the high-tech sectors that has contributed greatly to revitalizing the economic base of the Montreal region. A relatively young sector, which may be described as post-industrial, it has created high expectations as to its capacity to create jobs and economic wealth. Its many applications have created visions of sustained growth, arousing the interest of many public and private actors in the sector. The sector has fulfilled its promises in part and met a number of expectations, to such an extent that for a number of years it actually experienced labour shortage, raiding of workers, high wages, the creation of many firms and significant interest on the part of the financial community (Tremblay, 2002, 2004; Tremblay et al., 2002). In short, for a few years the sector was an unqualified success.

Unfortunately, in 2004, the reality is somewhat different. Yesterday's euphoria has given way to disillusionment as a result of significant changes in the multimedia landscape over the past two years. Today the multimedia sector is facing many daunting challenges,

\footnotetext{
${ }^{1}$ This is a modifed version of a paper presented at the Innovation Systems Research Network conference in May 2004 : Tremblay, D.-G. and Rousseau, S. (2004). Building an industrial Cluster and Governance : Mobilization of actors in the Montreal Multimedia Sector. ISRN Proceedings. Mc-Gill Queen's University Press. Forthcoming May 2005.

${ }^{2}$ Diane-Gabrielle Tremblay is doctor, professor and Canada Research Chair on the Socio-Organizational Challenges of the Knowledge Economy at Télé-université- Université du Québec .

(www.teluq.uquebec.ca/chaireecosavoir) and Serge Rousseau is Ph.D. candidate in Urban studies and research assistant on this project.
} 
mainly since the Government of Quebec withdrew its support for the sector by eliminating its funding for job creation in the Cité du multimédia. The withdrawal of significant government support, which is attributed to the change of provincial government in April 2003, is an important element of uncertainty, one that is exacerbating the difficult economic situation that has plagued the sector since the technological bubble burst in October 2000.

This paper will examine the mechanisms of governance set up by actors in the Montreal region in order to build the foundations of a new industry. We will discuss the factors that helped to trigger or motivate the mobilization of the actors involved in creating this sector. Obviously, when we talk about the multimedia sector in the global context of the Quebec economy (Tremblay and Van Schendel, 2004), politics remains a key element in our understanding of sectoral dynamics. We will hypothesize that the governance that has been established is reactive, that is, it is the product of a reaction rather than of longstanding, proactive planning. We will also see that governance has evolved over the years according to information and changes in the environment and involves a diversity of actors.

This paper will discuss the dynamics of governance in the multimedia sector in the Montreal region, more specifically, the motives underlying the creation of governance, the different actors involved, their role and its evolution over the years. We will demonstrate that the government has been a key actor, through the implementation of many tax measures promoting job creation, but especially through the creation of Cité $d u$ Multimédia in Old Montreal.

As regards methodology, it should be underlined that the results presented come from a survey carried out in 2003 in the multimedia sector, mainly in the Montreal region. We interviewed 75 individuals who work in the different spheres of this cluster -the multimedia firms, as well as the venture capital corporations, economic development organizations, different public administrations and consultancy firms. The face-to-face interviews followed a semi-structured questionnaire and lasted one and a half to two hours on average.

Before turning to the analysis of governance in the multimedia sector, we will first define what we mean by the multimedia sector and the notion of governance.

\section{Definition of the sector}

According to the various definitions put forward, the term multimedia refers to an information technology that can be used to simultaneously manipulate sounds, images and texts using one suite of software interactively (Tremblay, Chevrier and Rousseau, ISRN, 2004). By extension, a multimedia product is the result of the integration or transformation of the contents of multiple sources, such as texts, voices, data, images, graphics and video. This integration takes place in environments of interactive communications which can be disseminated digitally using a fixed support (CD-ROMs, DVDs, diskettes, etc.) or via a network (Internet, Intranet or Extranet). 
In Quebec like elsewhere, multimedia should be viewed as an emerging sector. Four categories of organizations operating can be identified in the multimedia sector. First, the multimedia producers, who make up the core of the sector, are responsible for multimedia applications. Second, some firms in traditional sectors (media, telecommunications, creative industries, advertising agencies, etc.) are attributing more and more importance to the development of multimedia applications in the context of their activities, in both areas of production and dissemination of contents. Third, manufacturers of the products and material needed for creation and dissemination, but also for the use of multimedia applications. Finally, an increasing number of representation, training and research organizations revolve around the multimedia sector. In Quebec, the best known organizations are Alliance Numériqc, Réseau Interlogiqc, Centre NAD, the Institut national de l'image et son (National Institute for Image and Sound), and the Regroupement des producteurs en multimédia (Association of multimedia producers).

The contours of the multimedia sector are difficult to determine. Because its boundaries tend to be vague, available statistics on the sector are often partial and incomplete. Today (2004), it is estimated that there are between 1200 and 1500 multimedia firms in Quebec. This is a clear regression since more than half of the firms appear to have disappeared, compared to 1999 data. The Institut de la statistique du Québec estimated that there were approximately 3200 multimedia firms in 1999 (Tremblay, Chevrier and Rousseau, 2004 and Chrétien, 2004). The sector has certainly experienced a degree of local consolidation of firms through mergers and acquisitions. However, the sharp decline in the number of firms can be explained essentially by the large number of firms that have had to close down. According to data gathered by Alliance Numériqc in November 2003, there were between 11,000 and 13,000 jobs in Quebec's multimedia sector.

As concerns the notion of governance, it refers to a dynamic process. Governance is the result of a construction that is part of a temporal process. This temporal process refers, on the one hand, to a past process of acquiring knowledge, skills and experience and, on the other hand, to the future characterized by the capacity of different agents to anticipate, hope for and thus to create a capacity for ideation. Nevertheless, this construction does not eliminate the possible divergences of interests between the actors but refers to the means of action that allow them to achieve common goals by finding compromises between sometime divergent interests and goals. Governance relies on efforts to find a consensus and creates the possibility of taking action in an environment where uncertainty often reigns.

\section{Constructing Governance in Montreal's Multimedia Sector}

Although the multimedia sector is relatively young, it does nevertheless have some history and the current situation is in large part the result of the past and of past governance. The arrival of the French game company Ubisoft permanently upset the Montreal landscape and triggered the construction of governance in the Montreal space. Thus, our starting point will be the establishment of this firm. We will briefly present the main stages of the firm's establishment and the actors associated with it. We will then examine the many highly mobilizing consequences of its establishment. On the one hand, mainly under the leadership of local firms, local actors were intensively mobilized and, on the other, institutionalized relations were established between the provincial 
government and the different actors working in the multimedia sphere. Finally, we will provide an assessment of this governance and its achievements in the Montreal space. This analysis will be based on information gathered in 75 interviews conducted in the sector, as we stated earlier, as well as on archival documents (general and specialized press articles).

\section{The start of it all: the Arrival of Ubisoft}

The arrival of the French firm Ubisoft ${ }^{3}$ in the Montreal region was an important milestone in the development of the city's multimedia sector. The firm, which specializes in entertainment, more specifically recreational games that can be used on different consoles, was looking for a location where it could set up in order to position itself in the North American market. Although the firm's establishment was an important element in the construction of this sector, it would be wrong to credit it with the sector's birth. In fact, prior to the arrival of Ubisoft, a number of firms already existed, but the sector was viewed as marginal and enjoyed little recognition at the various government levels.

Sylvain Vaugeois, the well-known Quebec lobbyist, was the instigator and promoter of the project to establish Ubisoft. He developed a highly specific and original strategy, called the Plan Mercure. Instead of providing financial support to firms through tax credits or large investments in their fixed assets, the plan proposed that the government invest in the labour force ( $\$ 25,000$ annually per employee for five years) in the promising multimedia sector The Plan Mercure was presented to the provincial government but received little support because it was seen as too expensive from the point of view of public finance.

In the end, the Minister of Human Resources Development agreed to subsidize the creation of 500 jobs over a five-year period, at a rate of $\$ 10,000$ per person per year. ${ }^{4}$ The goals of the federal government in taking this measure were simple: it wished to strengthen the positioning of Montreal as a world multimedia centre and make the most of the potential spill-over effect of the French firm's arrival. Ubisoft will finally benefit from a grant of $25000 \$$ per employee, as planned initially in the Plan Mercure. The Québec government contributes 15000 \$ while the federal contributes $10000 \$$ per employee.

The incentives offered were so generous and tempting that they succeeded in convincing Ubisoft to choose the Montreal region as the location from which to launch its North American expansion. In return for setting up business in Montreal, Ubisoft undertook to create 500 jobs over a five-year period. In 1997, it set up on Montreal's Saint-Laurent Boulevard in the former offices of the firm Discreet Logic, which was going to relocate in Faubourg des Récollets in Old Montreal. As we shall see further on, this relocation was also important because it had significant effects on the sector's dynamics.

\footnotetext{
${ }^{3}$ The firm was founded in France in 1986 by the Guillemot brothers.

${ }^{4}$ The formula chosen by the federal government was a discretionary form of assistance provided on an exceptional basis. Obviously the sector's actors contested this intervention. Faced with this dissatisfaction, Ottawa promised that firms with promising projects could obtain similar assistance.
} 
Today, Ubisoft employs nearly 700 of the 1200 people working in Quebec's electronic games industry. In addition, Ubisoft expects to hire an additional 150 people in 2004. Over the years, the Montreal subsidiary has become the largest of Ubisoft's 12 subsidiaries. It was entirely responsible for the design of the game Splinter Cell, which has sold more than five million copies and is considered to be a formidable success according to this industry's standards. The French firm, the third ranking game publisher in Europe and the sixth in the United States, is considered to be a giant in the electronic games industry (La Presse, 2003).

It therefore appears that Ubisoft has made a major contribution, with the multimedia subsector helping to position the Montreal region on the world map. The arrival of Ubisoft institutionalized what seemed at the time to be a marginal sector. The arrival of the French firm has also created an atmosphere that is conducive to developing the sector. Thus, Ubisoft has greatly contributed to raising the profile of Montreal's video game sector.

\section{Mobilization of Actors}

The emergence of the multimedia industry and information highways has been accompanied by the appearance of new coalitions and associations that would not have existed within the old economy. Since 1995, the local community has become highly mobilized and many associational structures have been formed. Among the most important are the Forum des inforoutes et du multimédia (FIM, information highway and multimedia forum), the Centre d'Expertise et de Services Applications en multimédia (CESAM, centre for multimedia expertise and application services), and the Association des Producteurs du Multimédia du Québec (APMQ, Quebec multimedia producers association).

In reaction to the considerable advantages accorded to the French firm, the multimedia sector firms organized themselves, rallying all the local actors gravitating around it. The local community mobilized itself and asked for government assistance similar to what was offered to Ubisoft.

That was the beginning of recognition for the sector and of the institutionalization of the relationship between the local multimedia sector firms and the Quebec government. From then on, the sector would be seen as a distinct sector with specific needs.

In terms of actors' mobilization, a distinction should be made between two movements which, of course, have definite points of convergence, but also somewhat different goals. The first movement can be described as having a sectoral vision, essentially seeking institutional recognition of the local industry. The aim of this institutional recognition is to receive assistance similar to what the governments gave Ubisoft. The second movement can be identified with a spatial vision, focusing on issues related to the ways of appropriating space and the desire to be part of the future mission of the territory. 
Having addressed spatial mobilization in an earlier text (Tremblay, Klein, Fontan and Bordeleau, 2002), the present paper will focus essentially on sectoral mobilization.

\section{Actors in sectoral mobilization}

Social and sectoral mobilization can and often does play a crucial role in governance structures and governance outcomes (Klein et al. 2004; Klein, Tremblay and Fontan, 2003, 2003a). Following the Quebec government's announcements regarding the establishment of CDTIs ${ }^{5}$ (Carrefour pour le développement des technologies de l'information - centres for the development of information technology), discontent intensified and could be heard from all quarters. The source of this dissatisfaction was related to the eligibility criteria for the CDTIs, which were seen to prevent Quebec firms from benefiting from the same advantages as foreign firms. Starting in February, local multimedia industry representatives were consulted about the Cyrenne plan and they clearly stated their disagreement with the plan's recommendations due to the following reasons: first, only firms created after the provincial budget were eligible and, second, they could not be the continuation of an already existing firm. However, foreign firms such as Ubisoft could carry out in Quebec the activities that they already operated abroad and still be eligible for the tax credits offered by the CDTI. Then, the criteria for location also became points of contention. The requirement that firms first locate in the CDTI and then later in Cité du multimédia were the focus of debate between the government and local associations. Moreover, it was as a result of these discussions that the CDTI concept evolved into the Cité du multimédia. Except for location in designated zones, most of the obstacles were removed through gains for the local producers.

In order to defend their position, some firms decided to act collectively within organizations, mainly three associations which we will describe below. The local actors thus convinced the government to modify the eligibility criteria to the CDTI. The detail of these associations' requests will be presented further on.

The Centre d'Expertise et de Services Application Multimédia (CESAM) was created in 1995 at the instigation of the Centre de recherche en informatique de Montréal (CRIM, Montreal centre for research on information engineering). CESAM is not an association but a business group that hoped in this way to create a critical mass that would allow it to take a leadership position in this potentially fast-growing industry. CESAM's goals were, among others, to establish a technological watch centre, to promote multimedia training, to incubate businesses, and to make the influence of Quebec's multimedia industry extend further.

CESAM was selective; because of the high annual fees, only large firms could afford to join. The fee for firms with annual sales of less than $\$ 20$ million was $\$ 15,000$ and $\$ 25,000$ for those with annual sales over $\$ 20$ million. CESAM (25 members) was made up of the industry's major firms. ${ }^{6}$ The association administered government funds to manage assistance and support programs for firms. ${ }^{7}$

\footnotetext{
${ }^{5}$ The advantages obtained by firms will be presented further on.

${ }^{6}$ Its members included large telecom, IT and publishing firms such as Vidéotron, Téléglobe, General Datacomm, Transcontinental e-media, Québécor multimédia, Bell Canada, CAE Electronique, Concordia
} 
The second largest association was the Association des producteurs en multimédia $d u$ Québec (APMQ). It was created spontaneously in the wake of the controversy surrounding Ubisoft's arrival in April 1997. In fact, the arrival of Ubisoft was a good thing because it spurred the industry to take charge of itself and the Quebec government to demonstrate that it was sensitive to the sector's problems.

The members of APMQ (firms only) thought that CESAM did not meet the aspirations of small firms. From the beginning, APMQ was determined to stand out from the associations that promoted producers and facilitated networking, such as the Forum des inforoutes et du multimédia (FIM) or the Centre de promotion du logiciel québécois (CPLQ, Quebec software promotion centre). ${ }^{8}$ Rather it saw itself as an association of lobbyists.

APMQ defended the interests of entrepreneurs. The association strove to defy international competition but was also interested in high visibility issues such as the protection of intellectual property in the new media and improving the working conditions of the artists. It was also on the front line over the Cite du multimedia issue. APMQ had argued in favour of the other firms - those located outside the designated zone and those that did not wish to move into la Cité to be able to benefit from funding. It wanted to reach an agreement that would allow producers who did not want to move into la Cité to benefit from advantageous though less generous conditions. However, it did not succeed.

The third player was the Forum des inforoutes et du multimédia. In June 1996, about 15 distributors, developers and others, concerned by the multimedia explosion, founded this forum. A non-profit organization, FIM's mission was to promote the digital content and interactive applications industry. Some 120 people attended the organization's first public activity. Unlike the two previously mentioned organizations, FIM was open to all individuals. It acted as a forum for debate and discussion on the important issues of the day. In particular, it initiated important discussions that took place during 1998 on the issue of the evolution of Internet advertising and was responsible for the creation of the Bureau de la publicité sur Internet au Québec (Internet advertising bureau in Quebec). In April 1999, it received funding from the ministère de la Culture et des Communications (ministry of culture and communications) to produce training tools and hold seminars aimed at getting advertisers to increase their use of the Internet as an advertising medium.

In December 2000, the members of the Association des producteurs en multimédia du Québec (APMQ), the Consortium multimédia (CESAM) and the Forum des inforoutes et du multimédia (FIM) approved a joint agreement to create Alliance numériQC, a merger of CESAM and FIM. APMQ survived the process under a new name, the Bureau des

\footnotetext{
University, CDedrom-Sni, le Centre National d'animation et de Design (NAD), Digital Equipment, Famic, the Groupe conseil Innovitech, the Groupe Image Buzz, Silicon Graphics, the Société Radio-Canada (SRC) and SoftImage/Microsoft.

7 In December 1997, CESAM received \$4.7 million from the federal and provincial governments (Federal Office of Regional Development (\$2.2 million), Minister of State for Greater Montréal and ministère de l'industrie du Commerce, de la Science et de la Technologie (\$2.5 million)). It obtained the equivalent from the private sector for total investments of $\$ 10$ million.

${ }^{8}$ Known today as Réseau Interlogiqc.
} 
producteurs en contenu interactif (BPCI, bureau of interactive content producers). ${ }^{9}$ It preserved one component of its programming, the management of labour relations between the multimedia artists and producers. BPCI would eventually negotiate collective agreements between multimedia producers and artists' unions. Two hypotheses can be used to explain this regrouping of the various associations. The first suggests that the regrouping is a more effective way to bring out a global vision of the industry. The existence of different organizations made it difficult to implement common action and a coercive vision. The second hypothesis relates to the wishes of the governments, ${ }^{10}$ which had strongly insisted that the associations join together for logistical reasons. In fact, the government authorities did not want to continually negotiate with the three associations. They believed that such a merger would simplify matters, thus reducing costs but especially reducing potential conflicts and the need to arbitrate between the groups. Both hypotheses have their defenders and are no doubt valid and complementary.

Alliance numériQC is a non-profit organization which is supported by the federal government (Economic Development Canada) and the provincial government (ministère de la Culture et des Communications du Québec and ministère du Développement économique et Régional). Today, it has 238 members, $75 \%$ of which are private firms. Most of these firms are micro-enterprises and SMEs operating in different niches, for example E-learning, games, Internet applications, etc. The alliance takes action in three main areas. The first is support to firms in their marketing, finance, and market watch and information activities. The second involves the development of skills, that is, the transfer of skills and knowledge, skills training and development and raising awareness among the different actors (governments, firms, educational institutions). The third area concerns relations with governments, and the role of interfacing with governments. Within this association, committees called Réseaux d'intérêt d'Alliance numériQC (RIAN, interest networks) have been created. These committees are intended for all stakeholders in the digital industry who are members of the association. They are formed at the initiative of people who wish to discuss subjects of common interest, often by subsectors. It should also be mentioned that the alliance encourages networking among the firms themselves, but also with other stakeholders such as universities, research centres, etc.

\section{Government response}

The local producers were dissatisfied with two aspects of government's response. First, they wanted to obtain the same advantages as those given to Ubisoft. But the provincial government reacted to this dissatisfaction by setting up the CDTI and subsequently the Cité du Multimédia. However, these measures did not meet the expectations of local producers. Second, they were against the idea of being confined to designated zones so as to qualify for government assistance. They were also against the conditions imposed for setting up business in these zones, mainly the requirement that activities could not be the

\footnotetext{
${ }^{9}$ It later became the Regroupement des producteurs de multimédia du Québec.

10 The 2000 provincial budget also recommended that the merger of the three organizations would be viewed very positively. In other words, the budget clearly stipulates that the Government of Quebec would invest in these associations on the condition that they group together.
} 
continuation of existing activities. The local producers pointed out that Ubisoft was not obliged to set up in these zones even though its activities were simply the extension of those carried out elsewhere. The government reacted by abolishing a number of criteria and proposing alternative measures. Amongst the criteria that were abolished, the main one was that firms be entirely new firms or that the specific activities covered be new. Various new measures will be developed to sustain these firms (see table 1).

Numerous actors within the governments and the ministries with an economic, technological, cultural and regional development mission were interested in the multimedia sector. This interest was based on two factors: first, the broad definition of multimedia allowed many firms to qualify for government assistance and, second, the sector seemed to have such a promising future.

The Government of Quebec made the multimedia sector an important element in its economic development policy. It foresaw an enormous potential for job creation in this sector, particularly for young people. Indeed, the speed at which the various measures were introduced appears to confirm the government's interest in this area -- in less than two years, a definite economic policy was implemented in this sector. Through these various measures, the provincial government's intention was to promote the investment in local firms in addition to attracting foreign firms ${ }^{11}$ to follow the trail blazed by Ubisoft. As will be seen below, numerous actors were involved in the implementation of a range of measures to support the development of the multimedia sector in the Montreal region.

The federal government also got involved. The multimedia sector fitted well into its national policy centred on the development of a knowledge-based economy (Government of Canada, 2001). Moreover, the federal government wanted to position the Montreal region as a multimedia centre on the world stage. Just like the provincial government, but to a lesser extent, it introduced numerous measures conducive to the industry's development. Just like the provincial government, several ministries and government agencies were interested in the multimedia sector (Canada Economic Development, Industrial Research Assistance Program, etc.).

Two major types of interventions to promote the development of this sector can be identified: general measures and specific measures.

General measures, which are numerous and varied, are not directly intended for firms. For example, the provincial government invested in the introduction of multimedia training programs in CEGEPs. Preferential purchase measures were also introduced. ${ }^{12}$ In more concrete terms, in its 2000 Budget, the provincial government invested \$343 million to turn Quebec into a wired society. This strategy is mainly based on three measures: first, a \$125-million budget to help connect 200,000 low-income families; and second, a $40 \%$ tax credit granted to SMEs wishing to set up a transactional Web site (\$126 million over three years). Third, \$15 million were earmarked for the deployment

\footnotetext{
${ }^{11}$ They had hoped to attract a ratio of $50 \%$ foreign firms $/ 50 \%$ Quebec firms.

${ }^{12}$ According to the individuals interviewed, particularly in E-learning, the government completely abandoned this policy which had provided business opportunities and was highly appreciated by firms.
} 
of a fibre optic network in the region to support local electronic trade activities. It must be stressed that the federal government also introduced similar measures.

Specific measures are directly centred on the development of firms and can include two sources: public or private funding. Though fewer in number, private financing includes venture capital corporations (Fonds de solidarité of the FTQ) and private funds (Fonds Bell or the Fonds de Daniel Langlois- creator of Softimage). Public financing from the ministries makes up almost all of the assistance granted to firms. These measures have been presented in detail elsewhere (Tremblay, Chevrier and Rousseau, 2004); they include programs, grants, tax credits, investment in capital stock and loans offered to firms.

The various governmental measures have several goals and can be associated with the following government policies: sectoral policy, spatial policy and cultural policy. Since spatial policy has already been examined in a previous article (Tremblay, Klein, Fontan, Bordeleau, 2001), we will deal with it only briefly below.

It should also be mentioned that the programs are intended either for all sectors or for the multimedia sector only. The latter are obviously more recent but often contain more constraints, in particular in terms of location and percentage of activities pertaining to multimedia.

Spatial Policy

First, it should be mentioned that any policy related to a multimedia firm, at least in Quebec, is highly spatialized. This is true because $90 \%$ of multimedia activities are concentrated in the Montreal region (Manzagol et al., 1999). It should be recalled that the spatial policy is essentially shaped through the Centres de développement des technologies de l'information (CDTIs) and the Cité du multimédia

In 1997, the provincial government first developed a program promoting the establishment of CDTIs. CDTIs drew on the formula of business incubators and applied to a building designated by the Ministère des finances, in which eligible firms received substantial grants. The firms must carry out all their activities inside this building. To be eligible, they must create new jobs. This was done to prevent existing firms from moving into the building to take advantage of the government measures. However, these can include new subsidiaries or existing firms which develop a new project or service.

In Montreal, the designated building is on Queen Street in the historic area of Old Montreal, ${ }^{13}$ more precisely in the Faubourg des Récollets. The building is a former plant that originally housed textile activities. This building was equipped with high-tech equipment (fibre optic) to serve the firms in the building.

A new program was created in 1998, Cité du multimédia, and put under the responsibility of the Bureau des Centres de développement des technologies de l'information, which broadened, in both the literal and figurative senses, its assistance to the multimedia sector. The goals of the Government of Quebec regarding Cité du multimédia were highly ambitious, ${ }^{14}$ since it hoped that the Cité would generate nearly 10,000 jobs

\footnotetext{
${ }^{13}$ The other CDTIs are located in the former building of the newspaper Le Soleil in Québec City, in Hull Technopark, in the Parc scientifique et de haute technologie in Laval and on Wellington Street in Sherbrooke.

${ }^{14}$ When the Cité $d u$ multimédia program was announced, the Quebec industry had 600 firms which provided jobs to 3400 people. Minister Landry pointed out that $40 \%$ of these firms did not exist three
} 
over a 10-year period. The measures proposed were relatively similar to those of the CDTI. However, rather than applying to a building, they applied to a larger physical space, several blocks around the CDTI.

Table 1 presents the specific government measures available to firms if they meet the eligibility criteria.

To provide firms operating in these designated spaces with the ready cash needed to carry out their activities, the provincial government provided for a temporary tax credit funding program, the Programme Garantie PME (SME guarantee program) under the tax credit temporary financing component, which was administered by Investissement Québec. Moreover, although the buildings in which firms were going to set up business were not built yet, the firms could nevertheless benefit from the allocated tax credits if they had signed a lease.

Table 1

Modes of government support associated with the two measures

\begin{tabular}{|c|c|c|}
\hline Forms of support & Innovative project & Cité du Multimédia \\
\hline Tax holiday for foreign experts & Income tax exemption (5 years) & Income tax exemption (5 years) \\
\hline Tax holiday & $\begin{array}{l}\text { From income tax } \\
\text { From capital tax } \\
\text { From employer contributions to } \\
\text { FESS } \\
\text { Period: first } 5 \text { years }\end{array}$ & \\
\hline $\begin{array}{l}\text { Tax credit for acquisition or lease } \\
\text { of eligible specialized material }\end{array}$ & $\begin{array}{l}\text { Material purchase } 40 \% \text { of capital } \\
\text { cost (first } 3 \text { years of the tax } \\
\text { holiday) } \\
\text { Lease of material: } 40 \% \text { of lease } \\
\text { cost (first } 5 \text { years of tax holiday) }\end{array}$ & \\
\hline Refundable tax credit on wages & 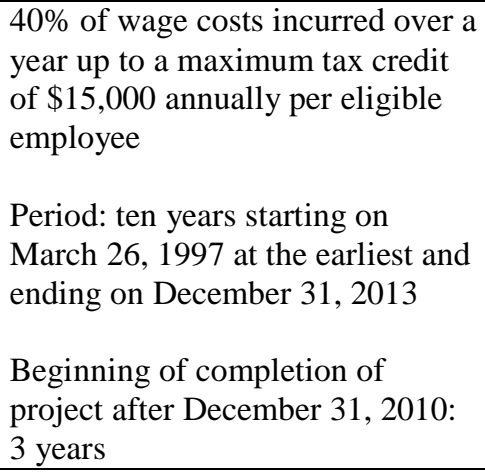 & 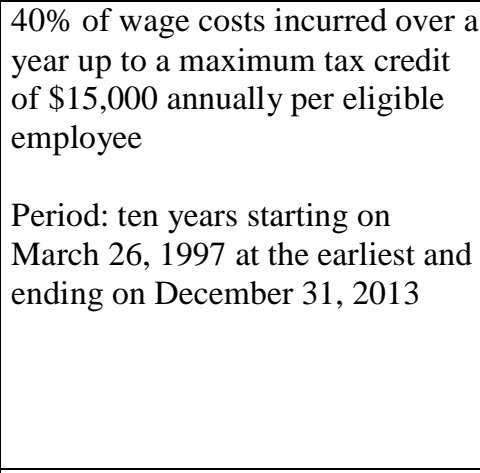 \\
\hline $\begin{array}{l}\text { Programme Garantie PME volet } \\
\text { Financement intérimaire de } \\
\text { crédits d'impôt } \\
\text { Administered by } \\
\text { Investissement Québec }\end{array}$ & $\begin{array}{l}\text { Improve firms' cash assets by } \\
\text { ensuring that their scientific } \\
\text { research and experimental } \\
\text { development (SRED) refundable } \\
\text { tax credits are funded by } \\
\text { Revenue Quebec and Revenue } \\
\text { Canada; }\end{array}$ & $\begin{array}{l}\text { Improve firms' cash assets by } \\
\text { ensuring that their scientific } \\
\text { research and experimental } \\
\text { development (SRED) refundable } \\
\text { tax credits are funded by } \\
\text { Revenue Quebec and Revenue } \\
\text { Canada; }\end{array}$ \\
\hline
\end{tabular}

Source: Bordeleau (2003) and Alliance NumériQC, Internet site

In April 2003, a new government was elected in Quebec, with the Liberal Party replacing the Parti Québécois, which had initiated the measures to support the multimedia sector. While the multimedia sector had been viewed very favourably by the PQ government, the

years ago (Le Soleil, 16/6/1998). The provincial government even hoped that the multimedia sector would employ as many people as the aeronautics industry or even the pulp and paper industry. 
LP government saw things differently. Multimedia firms (mainly those located in the Cité) were concerned about this change and there was already uncertainty in the multimedia sector, which had begun to be affected by a reduction in grants from the previous government. ${ }^{15}$

Firms in the sector had good reason to be worried. In fact, in the 2003 provincial budget, the Minister of Finance announced the termination of tax advantages granted to firms in the technology sector in the designated zones. ${ }^{16}$ In his view, the maintenance of 12,000 jobs and the creation of 5,000 other jobs in the designated zones would have required a total public investment, in the form of tax credits, of up to $\$ 4.5$ billion by 2010 . Moreover, according to the Minister, out of the 17,000 jobs linked to the designated zones, 12,000 already existed. In light of this conclusion, the tax credit programs were not expected to last much longer.

However, it should be specified that the new government will respect the commitments made to firms already established in the Cité. Firms that have not moved into a site but have received their approval certificate can also obtain the tax advantages provided.

Moreover, firms that are expanding will continue to receive tax credits on new employees' wages. However, the government has reduced the leasable areas of eligible buildings on the various sites, so that the tax credit will no longer be available beyond a certain expansion. Three sites are targeted, including the Cité du multimédia. Its area was decreased by 110,000 square metres and Phase VIII (a huge building currently on sale) was cut. It should be added that the Cité du multimédia was sold to a Toronto real estate developer in early 2004 (except for the building that corresponds to Phase VIII).

Another measure of the 2003 Budget went through relatively unnoticed. The Minister of Finance imposed a serious constraint on firms that are already registered in the program and continue to receive grants. In the case of control acquisition, the registered firms will no longer be able to receive tax exemptions. In other words, if a subsidized firm is bought by a competitor, it will immediately lose its tax advantage. In theory, this new government measure reduces the value of the firm for a potential buyer.

\section{Sectoral policy}

In addition to the Cité du multimédia measure, the Government of Quebec offers a wide range of new and existing assistance programs to firms that set up both within and outside the Cité. These include programs to assist with pre-startup, startup, capitalization, export, dissemination, distribution, production, international marketing, development and R\&D. While these last measures are not exclusive to multimedia, they nevertheless play an important role in this sector.

According to Alliance numériQC, 11 provincial programs apply to multimedia firms. The main lending agencies are the Caisse de dépôt et de placement du Québec (Quebec

\footnotetext{
${ }^{15}$ In the last budget of the previous government, the Minister of Finance had opened the door to a decrease in the percentage of tax credits offered to the sector.

${ }^{16}$ It should be mentioned that the biotechnology centres were spared but their tax credits were decreased.
} 
deposit and investment fund) and its subsidiaries, the Société générale de financement et Investissement Québec (Quebec general finance and investment corporation). As Table 2 shows, the assistance provided pertains to all development stages.

Table 2. Provincial programs (Quebec)

\begin{tabular}{|c|c|c|}
\hline $\begin{array}{l}\text { Capital d'Amérique CDPQ } \\
\text { Managed by: } \\
\text { Caisse de dépôt et placement du } \\
\text { Québec }\end{array}$ & Capitalization & $\begin{array}{l}\text { Supports medium and large-sized enterprises } \\
\text { that have good return and growth prospects. } \\
\text { Investments are over } \$ 1 \mathrm{M} \text {, mainly in shares } \\
\text { and debentures. A long-term investor, the } \\
\text { Caisse shares in the profitability goals by } \\
\text { assisting firms in the different development } \\
\text { stages both in Quebec and abroad. As a } \\
\text { minority shareholder, the Caisse does not } \\
\text { intervene in the ongoing management of the } \\
\text { firm but makes an important contribution to its } \\
\text { strategic development. }\end{array}$ \\
\hline $\begin{array}{l}\text { Accès Capital } \\
\text { Managed by: } \\
\text { Caisse de dépôt et placement du } \\
\text { Québec }\end{array}$ & Capitalization & $\begin{array}{l}\text { Provides firms from all regions in Quebec with } \\
\text { various forms of ready capital. }\end{array}$ \\
\hline $\begin{array}{l}\text { Capital Communications CDPQ } \\
\text { Managed by: } \\
\text { Caisse de dépôt et placement du } \\
\text { Québec }\end{array}$ & Capitalization & $\begin{array}{l}\text { Supports firms' projects to expand in Quebec } \\
\text { and elsewhere in North America, Europe and } \\
\text { Asia, and to generate their optimal financial } \\
\text { performance while contributing to the } \\
\text { economic development of the sector. }\end{array}$ \\
\hline $\begin{array}{l}\text { Déclic PME } \\
\text { Managed by: } \\
\text { Investissement Québec }\end{array}$ & Start-up & $\begin{array}{l}\text { Assists firms with obtaining funding for } \\
\text { project start-up. The financial assistance is in } \\
\text { the form of a loan guarantee covering up to } \\
80 \% \text { of losses assumed by financial } \\
\text { institutions. Supports the start-up of new firms } \\
\text { or projects of existing firms. }\end{array}$ \\
\hline $\begin{array}{l}\text { Fonds pour l'accroissement de } \\
\text { l'investissement privé et la } \\
\text { relance de l'emploi (FAIRE)- } \\
\text { Investissement Québec } \\
\text { Managed by: } \\
\text { Investissement Québec }\end{array}$ & Capitalization & $\begin{array}{l}\text { Stimulates investment and job creation in } \\
\text { Quebec by sharing the benefits of the } \\
\text { economic spin-offs of their projects with } \\
\text { firms. The financial intervention must provide } \\
\text { incentive for the project to take shape. }\end{array}$ \\
\hline $\begin{array}{l}\text { Impact PME } \\
\text { Managed by: } \\
\text { MIC }\end{array}$ & Development & $\begin{array}{l}\text { Provides financial support to firms for market } \\
\text { development. Includes two components: } \\
\text { innovation and development of export } \\
\text { markets. }\end{array}$ \\
\hline $\begin{array}{l}\text { Programme Garantie PME } \\
\text { Managed by: } \\
\text { Investissement Québec }\end{array}$ & $\begin{array}{l}\text { Marketing } \\
\text { Export } \\
\text { Distribution } \\
\text { Dissemination }\end{array}$ & $\begin{array}{l}\text { Provides support to development by } \\
\text { guaranteeing funding of their projects with } \\
\text { financial institutions. }\end{array}$ \\
\hline $\begin{array}{l}\text { La Société financière } \\
\text { d'innovation SOFINOV } \\
\text { Managed by: }\end{array}$ & Capitalization & $\begin{array}{l}\text { Offers strategic funding to technologically } \\
\text { innovative firms with high potential for growth } \\
\text { and performance and whose avant-gardism }\end{array}$ \\
\hline
\end{tabular}




\begin{tabular}{|c|c|c|}
\hline $\begin{array}{l}\text { Caisse de dépôt et placement du } \\
\text { Québec }\end{array}$ & & brings a bright future. \\
\hline $\begin{array}{l}\text { Programme Garantie PME volet } \\
\text { Nouvelle économie } \\
\text { Managed by: } \\
\text { Investissement Québec }\end{array}$ & Capitalization & $\begin{array}{l}\text { Offers a financial product adapted to new } \\
\text { economy firms. This financial product takes } \\
\text { the form of a guarantee applicable to a loan } \\
\text { granted by a financial institution. }\end{array}$ \\
\hline $\begin{array}{l}\text { Société Générale de } \\
\text { Financement - Division Haute } \\
\text { technologie } \\
\text { Managed by: } \\
\text { Société Générale de } \\
\text { Financement }\end{array}$ & Capitalization & $\begin{array}{l}\text { Offers development capital. With private } \\
\text { partners, shares in risk and management to } \\
\text { contribute to the development of a technology, } \\
\text { product or both. }\end{array}$ \\
\hline $\begin{array}{l}\text { T2C2 - Transfert, Technologies } \\
\text { d'avant-garde, } \\
\text { Commercialisation optimale, } \\
\text { Capital interactif } \\
\text { Managed by: } \\
\text { Société financière d'innovation, } \\
\text { a subsidiary of the Caisse de } \\
\text { dépôt et placement du Québec }\end{array}$ & Capitalization & $\begin{array}{l}\text { Involved in the start-up of firms in health } \\
\text { sciences and information technology sectors, } \\
\text { provides bridge between research and } \\
\text { marketing of their results. Its mission is } \\
\text { closely linked to the demands of the new } \\
\text { economy: increase value of the portfolio of } \\
\text { technological innovations of universities, basic } \\
\text { and applied research centres of Quebec and } \\
\text { private sector }\end{array}$ \\
\hline
\end{tabular}

Source: Alliance numériQC Internet site.

There are three lenders at the federal level:

-National Research Council of Canada

-Business Development Bank of Canada

-Economic Development Canada

EDC subcontracts the management of its program to Alliance numériQc. It should be noted that before the merger of the three associations, CESAM also had a similar mandate.

Table 3. Federal programs (Canada)

\begin{tabular}{|c|c|c|}
\hline $\begin{array}{l}\text { Alliance stratégique entre la } \\
\text { Banque Nationale et la BDC } \\
\text { Managed by: } \\
\text { Business Development Bank of } \\
\text { Canada and the Banque } \\
\text { Nationale }\end{array}$ & $\begin{array}{l}\text { Marketing } \\
\text { Export } \\
\text { Distribution } \\
\text { Dissemination }\end{array}$ & $\begin{array}{l}\text { For a three-year period, a sum of up to } \$ 60 \\
\text { million is provided to knowledge economy } \\
\text { firms and innovative manufacturers that export } \\
\text { their products. }\end{array}$ \\
\hline $\begin{array}{l}\text { Young Entrepreneur Financing } \\
\text { Program } \\
\text { Managed by: } \\
\text { BDC }\end{array}$ & Pre-startup & $\begin{array}{l}\text { Provides young entrepreneurs aged } 18 \text { to } 34 \\
\text { with a solid foundation on which to build a } \\
\text { firm. Individuals that have a commercially } \\
\text { viable business plan with excellent potential } \\
\text { can obtain a loan of up to } \$ 25,000 \text { and } 50 \\
\text { hours of personalized management support to } \\
\text { help their firm get off the ground. }\end{array}$ \\
\hline $\begin{array}{l}\text { IRAP Industrial Research } \\
\text { Assistance Program }\end{array}$ & $\begin{array}{l}\text { Research and } \\
\text { development }\end{array}$ & $\begin{array}{l}\text { Helps Canadian small and medium-sized } \\
\text { enterprises (SMEs) to meet the technological }\end{array}$ \\
\hline
\end{tabular}




\begin{tabular}{|c|c|c|}
\hline $\begin{array}{l}\text { Managed by: } \\
\text { National Research Council of } \\
\text { Canada (NRCC) }\end{array}$ & & $\begin{array}{l}\text { challenges of developing new products, } \\
\text { processes or services. The goal is to increase } \\
\text { innovative capacity in order to turn good ideas } \\
\text { into profitable areas of activity as quickly as } \\
\text { possible. }\end{array}$ \\
\hline $\begin{array}{l}\text { Fonds d'expérimentation en } \\
\text { multimédia } \\
\text { Managed by : } \\
\text { Alliance numériQC }\end{array}$ & Capitalization & $\begin{array}{l}\text { Offers pre-startup support for projects in the } \\
\text { multimedia sector. }\end{array}$ \\
\hline $\begin{array}{l}\text { IDEA - SME } \\
\text { "Innovation, research and } \\
\text { development, design" } \\
\text { Managed by: } \\
\text { EDC }\end{array}$ & $\begin{array}{l}\text { Research and } \\
\text { development }\end{array}$ & $\begin{array}{l}\text { SMEs are the targeted clientele of Economic } \\
\text { Development Canada. Other categories of } \\
\text { clients may also be eligible for financial } \\
\text { assistance if their proposals contribute to the } \\
\text { development of SMEs and the agency's } \\
\text { priorities. EDC concentrates its efforts on } \\
\text { firms that generally have fewer than } 200 \\
\text { employees. }\end{array}$ \\
\hline
\end{tabular}

Source: Alliance numériQC Internet site

It should be mentioned that a number of important programs have disappeared. For example, the Programme d'aide à la recherche et développement, à l'amélioration des compétences en science et technologies (PACST) ${ }^{17}$ which was once in high demand, no longer exists.

While there seem to be many measures both at the provincial and federal levels, our interviews indicate that they are difficult to apply in the multimedia sector. The eligibility criteria are high and do not necessarily correspond to the specificities of the sector. Let us quote one person interviewed:

"projects considered are usually over the 10 million mark, and often well over that...it is difficult to put 10 million in a firm that is not valued at least 20 to 30 million...And in the multimedia sector, this basically does not exist. The industrial base is burgeoning, it is based on micro-entreprises, artisan businesses, really small SMbs in this sector..."

Also, for example, while the firms are often sole proprietorships, the funding agency may require participation in the form of capital stock.

«When we looked for financing to develop our products we discovered that many of the persons interested wanted a participation in the firm. This situation did not interest us. My associate and I did not want to lose control, we thought this would not be viable in the long term. »

It should be mentioned that more recently, the sector has been blacklisted as a result of the bursting of the Dotcom bubble. One of the main obstacles are the high costs in terms of time and resources needed to meet the requirements of these measures, which exclude many SMEs.

\footnotetext{
${ }^{17}$ For example, Discreet Logic has greatly benefited from this program.
} 


\section{Third Sector}

Besides the programs offered by the provincial and federal governements, there are other forms of aid that are offered to firms in the multimedia sector by various types of organizations, that we might call associative or third sector organizations. Many are of parapublic sector and we must add the Bell Fund, which is of the private sector. Each of these organizations have their own objectives and criteria. The support offered by these touch all dimensions of the business: startup, capitalization, distribution, etc.

Table 4. THIRD SECTOR PROGRAMS

\begin{tabular}{|c|c|c|}
\hline Name & Type & Description \\
\hline $\begin{array}{l}\text { Fonds d'investissement } \\
\text { Managed by: } \\
\text { Community Futures } \\
\text { Development Corporations } \\
\text { (CFDCs) of Quebec }\end{array}$ & Startup & $\begin{array}{l}\text { Provides additional financial support in the } \\
\text { form of loans or redeemable shares }\end{array}$ \\
\hline $\begin{array}{l}\text { Fonds de développement } \\
\text { Emploi-Montréal Inc. } \\
\text { Managed by: } \\
\text { Fonds de développement } \\
\text { Emploi-Montréal Inc. }\end{array}$ & Capitalization & $\begin{array}{l}\text { The mission of the fund is to contribute to the } \\
\text { economic development of Montreal districts } \\
\text { through investments in viable, cost-effective } \\
\text { firms that have demonstrated a structuring } \\
\text { effect in the targeted community and an } \\
\text { impact on the creation or retention of local } \\
\text { jobs. }\end{array}$ \\
\hline $\begin{array}{l}\text { Fonds de développement } \\
\text { Montréal } \\
\text { Managed by: } \\
\text { Emploi Montréal }\end{array}$ & Startup & Startup assistance \\
\hline $\begin{array}{l}\frac{\text { Fonds de la radiodiffusion et }}{\text { des nouveaux médias de Bell }} \\
\text { Managed by: } \\
\text { Bell Canada }\end{array}$ & Production & $\begin{array}{l}\text { Fosters partnerships between television } \\
\text { producers and new media. To do this, the fund } \\
\text { distributes } \$ 2 \text { million in grants annually for the } \\
\text { production of television programs linked to } \\
\text { Internet sites. }\end{array}$ \\
\hline $\begin{array}{l}\frac{\text { Inno-Centre }}{\text { Managed by: }} \\
\text { Inno-Centre }\end{array}$ & Startup & $\begin{array}{l}\text { The primary mission of all Inno-centre } \\
\text { collaborators - whether employees or } \\
\text { consultants - is to maximize the support given } \\
\text { to new entrepreneurs as part of the business } \\
\text { development program. }\end{array}$ \\
\hline $\begin{array}{l}\text { Innovatech Grand Montréal } \\
\text { Innovatech du sud du Québec } \\
\text { Innovatech Québec et } \\
\text { Chaudière-Appalaches } \\
\text { Managed by: } \\
\text { Innovatech Grand Montreal }\end{array}$ & Capitalization & $\begin{array}{l}\text { The mission of this venture capital company is } \\
\text { to promote and support initiatives specifically } \\
\text { aimed at increasing the capacity for } \\
\text { technological innovation in its territory and } \\
\text { thus to increase competitiveness and economic } \\
\text { growth while providing a return that ensures } \\
\text { its continued operation. }\end{array}$ \\
\hline $\begin{array}{l}\text { Francophone Information } \\
\text { Highway Fund }\end{array}$ & Education - training & $\begin{array}{l}\text { In the communications field, La Francophonie } \\
\text { is firmly committed to new information }\end{array}$ \\
\hline
\end{tabular}




\begin{tabular}{|c|c|c|}
\hline $\begin{array}{l}\text { Managed by: } \\
\text { The Intergovernmental Agency } \\
\text { of la Francophonie }\end{array}$ & & $\begin{array}{l}\text { technology and formally requests that } \\
\text { operators do everything possible to quickly } \\
\text { implement the action plan adopted at the } \\
\text { Conference of Francophone Ministers } \\
\text { Responsible for Information Highways, which } \\
\text { was held in Montreal on May 19-21, } 1997 . \\
\text { This action plan focuses on the following } \\
\text { seven points: } \\
\text { - Democratizing access to information } \\
\text { highways } \\
\text { - Development of education, training and } \\
\text { research } \\
\text { - Strengthening creation and circulation of } \\
\text { contents } \\
\text { - Promotion of economic and social } \\
\text { development } \\
\text { - Establishment of francophone watch } \\
\text { - Raising awareness of youth, producers and } \\
\text { investors } \\
\text { - The organized presence of Francophones in } \\
\text { international bodies responsible for the } \\
\text { development of information highways }\end{array}$ \\
\hline $\begin{array}{l}\text { Société locale d'investissement } \\
\text { dans le développement de } \\
\text { l'emploi } \\
\text { Managed by: } \\
\text { Community Economic } \\
\text { Development Corporations } \\
\text { (CEDCs) }\end{array}$ & Capitalization & $\begin{array}{l}\text { Invests in small startup or expansion firms by } \\
\text { granting capitalization loans varying from } \\
\$ 5,000 \text { to } \$ 50,000 \text {. }\end{array}$ \\
\hline $\begin{array}{l}\text { Fonds local investissement } \\
\text { Managed by: } \\
\text { Community Economic } \\
\text { Development Corporations } \\
\text { (CEDCs) }\end{array}$ & Capitalization & $\begin{array}{l}\text { Funds small startup or expansion firms by } \\
\text { granting loans varying from } \$ 3,000 \text { to } \\
\$ 65,000 \text {. }\end{array}$ \\
\hline
\end{tabular}

\section{Cultural policy}

Cultural policy can also be viewed as a manifestation theme of governance in the multimedia sector. The policy has three main orientations: the individual, (that is, the artist), the firm, and the sector. We will restrict our examination to measures that concern firms.

Among the best known measures in Quebec are the SODEC (Société de développement des entreprises culturelles) tax credit, which encourages the release of multimedia titles in French for the general public, as well a variety of funds: information highway, culture and communications, development of Montreal and of the national capital, and those associated with private investment growth and employment revitalization.

Basically, these measures support the diversification of cultural enterprises in the development and marketing of multimedia products (publishing and co-publishing), the development and marketing efforts of producers of multimedia titles whose products have 
demonstrated market potential and finally the distribution of Quebec multimedia products, both in Quebec and abroad. Various measures are offered through the SODEC, a government body.

We must add to this list the Financière des entreprises culturelles (FIDEC), a financial organization for the cultural industries created in 1999. It was created by the association of nine firms of the cultural and financial sectors. Amongts the creators, we find the Société de développement des entreprises culturelles du Québec (SODEC), the Fonds de solidarité des travailleurs du Québec (FTQ), the National Bank of Canada, the Tv group TVA, CINAR, Daniel Langlois (founder of Softimage), Remstar Corporation, France Film, DKD! Spectacle/Centre Molson and Rosaire Archambault. This new financial group has some 45,5 million in capital aimed at supporting Québec firms on the international scene. This firm offers financial products for cultural firms aiming at international markets, whether it be cinema, TV production, huge shows, or development of an artist's career. FIDEC offers means to the producers and distributors in Québec for very large projects, supporting them in the integration of new technologies and helping them support a rythm of production and commercialization at the international level.

At the federal level, the Multimedia Fund, announced in June 1998 by the Minister of Canadian Heritage, is a $\$ 30$ million fund covering a five-year period and administered by Telefilm Canada. Some other federal measures are presented in Table 5. It is generally considered that Quebec has often benefited from the federal government cultural policy, for example, in investments in television production, but there are no available studies specifically on the multimedia sector. This program supports Canadian multimedia products in both official languages (English and French). These products must be of high quality, original, interactive and intended for the general public. All Canadian multimedia development, production and publishing firms are eligible. However, small and mediumsized enterprises are given priority.

\section{Conclusion}

As was observed in this article, many actors intervene in the multimedia sector: public, private, associative, financial and many community actors. In this sense, there appears to be here a form of governance where there is participation of many social actors in the development and support of a real industrial policy aimed at the multimedia sector and aimed at making of Montreal an important center of multimedia development.

As was indicated, there were various plans put forward by various actors, but very quickly, the various levels of governement, federal and provincial, adhered to support the French firm Ubisoft. Local Montreal actors were then determinant in creating a social mobilization in order to obtain some support more or less equivalent to what had been offered to Ubisoft. The Montreal administration as well as some private actors in the financial, cultural and multimedia sector per se all supported at various levels and in various ways the development of this sector and of the firms of the sector.

There was consensus around the idea of developing this specific sector and over the years, firms were more and more interested in having some form of public intervention in order to support them in development of products, but even more in commercialization of these products. 
Also, as was shown in the paper, politics, governance structures and programs as well as social mobilization remain key elements in our understanding of sectoral dynamics in the multimedia sector in Québec. We have shown through our analysis that the governance structures created have been mainly of a reactive nature, that is, they were clearly the product of a reaction to the risk of Ubisoft settling elsewhere in Northeastern North America, rather than of long-standing, proactive planning. This is also understandable since the multimedia sector is recent and did require quick action in order to preserve a possibility of developing an industrial sector. We also illustrated through our paper how governance structures and outcomes have evolved over the years according to changes in the environment.

\section{Reference List}

Allemand, S. (2000) Gouvernance. Le pouvoir partagé. Sciences humaines 12-18.

Bagnasco, A. and Le Galčs, P. (1997) Villes en Europe, Paris: La Découverte.

Balme, R. (1996) Les politiques du néo-régionalisme. Action collective régionale et globalisation, Paris: Economica.

Bassand, M. (1997) Métropolisation et inégalités sociales, edn. Lausanne: Presses polytechniques et universitaires romandes.

Bordeleau, D. (2003) Gouvernance et construction teritoriale. Le cas du Faubourg des Récollets de Montréal: du carrefour des arts et des technologies ŕ la Cité du Miultimédia, Montréal: Université du Québec ŕ Montréal.

Chrétien, D. (2004) Les bagarreurs du multimédia. L'Actualité 29, 38-40.

Coase, R.H. (1937) The nature of the firm. Economica 386-405.

De Alcantara, C.H. (1998) Du bon usage du concept de gouvernance . Revue internationale des sciences sociales 109-118.

Esser, J. and Hirsch, J. (1989) The crisis of fordism and the dimensions of a 'postfordist' regional and urban structure. RIREUR

Fontan, J.-M. , J.-L. Klein et D.-G. Tremblay (2004). L'innovation sociale. Analyse à partir du cas de la reconversion de Montréal. Paris : L'Harmattan.

Fontan, J.-M., J.-L. Klein et D.-G Tremblay (2004a). Innovation et société : pour élargir l'analyse des effets territoriaux de l'innovation. Géographie, économie et société. Vol. 6, no 2. Paris : Elsevier. A paraître en octobre 2004.

Klein, J.L., C. Manzagol, D.-G. Tremblay, S. Rousseau (2004). Les interrelations université-industrie à Montréal dans la reconversion à l'économie du savoir. Dans 
Guillaume, R. (2004). Les systèmes productifs au Québec et dans le Sud-Ouest français. Paris : Ed. L'Harmattan. A paraître en octobre 2004.

Klein, J.L., Tremblay, D.-G. et J.M. Fontan (2003). Systèmes locaux et réseaux productifs dans la reconversion économique : le cas de Montréal. Géographie, économie et société. Vol. 5 no 1. Paris : Elsevier. Mai 2003

Klein, J.L., Tremblay, D.-G. et J.M. Fontan (2003a). Mundializacion, accion colectiva e iniciativa local en la reconversion de Montreal. Revista Latinoamericana de Estudios Urbanos y regionales. Vol. XXIX, no 86 mayo 2003. Santiago. Carlos de Matos. Pp. 59-75.

Kooiman, J. (1993) Modern Governance, London : Sage.

Le Galès, P. (1995) Du gouvernement des villes à la gouvernance urbaine. Revue française de sciences politiques 45, 57-95.

Manzagol, C., Robitaille, É. and Roy, P. (2000) Le multimédia à Montréal : le high-tech à la rescousse des espaces fatigués. In: Sénécal, G. and Saint-Laurent, D., (Eds.) Les espaces dégradés. Contraintes et conquêtes, pp. 201-217. Montréal: Université de Montréal]

Merrien, F.-X. (1997) De la gouvernance comme évolution convergente à la gouvernance comme arrangements contingents. In: Saez, G., Leresch, J.-P. and Bassand Michel, (Eds.) Gouvernance métropolitaine et transfrontalière. Action publique territoriale, pp. 271 Paris: L'Harmattan]

Pecqueur, B. (2001) Gouvernance et régulation: un retour sur la nature du territoire. Géographie, économie, société 3, 229-245.

Stoker, G. (1995) Urban Gouvernance in Britain. Sociologie du travail 301-315.

Stone, C.S. (1989) Regime politics: Governing Atlanta (1946-1988), Lawrence: Kansas University Press.

Tremblay, D.-G., Chevrier, C. and Rousseau, S. (2004) The Montreal Multimedia Sector: District, Cluster or Localized System of Production . In D. Wolfe and M. Lucas (eds, 2004). Clusters in a Cold Climate : Innovation Dynamics in a Diverse Economy. Montreal and Kingston : McGill-Queen's University Press and School of Policy Studies, Queen's University. pp

Tremblay, D.-G. (2004). Les districts à l'épreuve de la diversification : le cas du triangle d'or montérégien. Dans Guillaume, R. (2004). Les systèmes productifs au Québec et dans le Sud-Ouest français. Paris : Ed. L'Harmattan.

Tremblay, D.-G. et C.H. Amherdt (2004). Travail en réseau et développement des compétences dans le secteur du multimédia. Revue de Carriérologie. Vol. 9, no 3- 
4.

Tremblay, Diane-Gabrielle (2002). Informal Learning Communities in the Knowledge Economy; «Knowing Whom » as a source of Knowledge Development in the multimedia sector. In D. Passey et M. Kendall (dir., 2002). TelE-Learning: the Challenge for the Third Millenium. Proceedings of the 17 th World Computer Congress, Kluwer Academic Publishers, Amsterdam/New York. Pp. 241-248.

Tremblay, D.-G., Klein, J.-L., Fontan, J.-M. and Bordeleau, D. (2002) Modalities for the Establishement of the Relational Firm: A Case Study of The Cité du Multimedia, Montréal. In: Holbrook, A. and Wolfe, D., (Eds.) Knowledge Clusters and Regional Innovation: Economic Development in Canada, pp. 161-184. Kingston: Queen's School of Policy Studies and McGill-Queen's University Press]

Tremblay, Diane-Gabrielle et van Schendel, Vincent (2004). Economie du Québec; régions, , acteurs, enjeux. Montréal: Ed. Saint-Martin. 930 p.

Valaskakis, K. (1998) Mondialisation et gouvernance. Futuribles 5-28. 